A N N A L E S

UNIVERSITATIS MARIAE CURIE-SKŁODOWSKA

LUBLIN - POLONIA

VOL. LXIII, 1

SECTIO G

2016

Uniwersytet Marii Curie-Skłodowskiej w Lublinie

kdudek_radca@op.pl

KATARZYNA DUDEK

\title{
Konferencja naukowa poświęcona pamięci Giana Domenico Romagnosiego
}

Scientific Conference Dedicated to the Memory of Gian Domenico Romagnosi

W dniu 15 października 2015 r. na Wydziale Prawa i Administracji Uniwersytetu Marii Curie-Skłodowskiej w Lublinie odbyła się konferencja naukowa pt. „Historia nauki administracji i myśli administracyjnej. Konferencja naukowa poświęcona pamięci Giana Domenico Romagnosiego", zorganizowana z inicjatywy Katedry Doktryn Politycznych i Prawnych, Katedry Historii Państwa i Prawa oraz Katedry Prawa Administracyjnego i Nauki o Administracji. Komitet Naukowy stanowili prof. dr hab. Lech Dubel, prof. dr hab. Wojciech Witkowski oraz prof. dr hab. Marian Zdyb. Konferencja odbyła się pod patronatem honorowym Pani Dziekan Wydziału Prawa i Administracji UMCS prof. dr hab. Anny Przyborowskiej-Klimczak.

Spotkaniu towarzyszyła wystawa naukowa poświęcona życiu i twórczości Giana Domenico Romagnosiego oraz sesja posterowa stworzona przez studentów Wydziału Prawa i Administracji UMCS. W czasie konferencji odbyła się także prezentacja dwóch publikacji: Źródła normatywne do dziejów izb przemystowo-handlowych na ziemiach polskich (1918-2014) opracowanej przez Karola Dąbrowskiego oraz Dokumenty Archiwalne w zasobie Archiwum Państwowego w Lublinie opracowanej przez Rafała Bobrowca, Marcina Bubicza, Karola Dąbrowskiego, Artura Potockiego, Magdalenę Węcławską i Edytę Wlazło.

Konferencja została otworzona przez Panią Prodziekan Wydziału Prawa i Administracji, dr hab. Beatę Jeżyńską, prof. UMCS.

Na początku konferencji dr hab. Piotr Szreniawski odczytał list Ambasadora Republiki Włoskiej Alessandro De Pedysa, podkreślający wagę relacji pomiędzy 
Polską a Włochami w zakresie krzewienia kultury polsko-włoskiej oraz ukazujący rolę Giana Domenico Romagnosiego jako ojca myśli politycznej i prawnej we współczesnych Włoszech i w Europie.

Głównym bohaterem konferencji był włoski uczony epoki Oświecenia Gian Domenico Romagnosi, którego działalność i szerokie spektrum zainteresowań wywarły nie tylko ogromny wpływ na życie polityczne, społeczne i gospodarcze Włoch u schyłku XVIII stulecia i pierwszych dziesięcioleci XIX w., ale także stanowiły nieoceniony wkład w podwaliny włoskiego prawa. Jego rozległe zainteresowania obejmowały m.in. filozofię, ekonomię, prawo, matematykę oraz fizykę, w szczególności zjawisko elektromagnetyzmu. Jak dowiedzieliśmy się z prezentacji posterowej przedstawionej przez studentów Wydziału Prawa i Administracji UMCS, ogromny wpływ na Giana Domenica Romagnosiego miało społeczeństwo i jego ówczesne poglądy ujęte w formie doktryn polityczno-prawnych.

W pierwszym referacie, zatytułowanym „Gian Domenico Romagnosi - sylwetka badacza", dr hab. Piotr Szreniawski dokonał charakterystyki tej barwnej postaci oraz analizy jego twórczości. Autor wystąpienia ukazał Romagnosiego jako człowieka wszechstronnego. Wykonywał on bowiem zawód adwokata, notariusza, miał wykształcenie teologiczne i filozoficzne, stworzył projekt konstytucji zjednoczonych Włoch, zajmował się elektromagnetyzmem. Autor referatu wskazał, że pozwala to na uznanie, że ten włoski uczony powinien być traktowany jako geniusz łączący wiedzę z różnych dziedzin.

Sylwetka Giana Domenico Romagnosiego, zwolennika idei zjednoczenia Włoch, zrażonego do polityki napoleońskiej, silnie związanego z miastami północnych Włoch, zwłaszcza z Mediolanem, Trydentem i Parmą, została zaprezentowana także na tle historycznym. Tematyka ta została ujęta w referacie wygłoszonym przez mgr. Huberta Mielnika pt. „Napoleońskie byty państwowe na terytorium północnych Włoch - od Republiki Transpadańskiej do Królestwa Włoch". Autor referatu dokonał przeglądu zmian ustrojowych państw w północnych Włoszech w epoce napoleońskiej, omawiając przy tym szczegółowo byty państwowe od Republiki Transpadańskiej do Królestwa Włoch. Prelegent przeanalizował także poszczególne konstytucje oraz aspekty prawne ich funkcjonowania, poruszając na tym tle problematykę przyczyn zachodzących zmian państwowych. Główna teza referatu opierała się na stwierdzeniu, że w opisywanych państwach nie wprowadzono żadnego nowatorskiego elementu ustrojowego czy prawnego, ponieważ wszystkie konstytucje były co do zasady odwzorowaniem francuskich regulacji z 1795 i 1799 r. Podobnie było z prawem sądowym i administracją lokalną, które stanowiły recepcję francuskich wzorców. Prelegent ocenił również fakt wprowadzenia Kodeksu Napoleona, zastanawiając się jednocześnie nad przyczyną stworzenia przez Napoleona Bonaparte oddzielnych bytów państwowych zamiast włączenia terytorium północnych Włoch do Francji. Zdaniem autora główna przyczyna leżała w potrzebie zaspokojenia społeczno-narodowych 
potrzeb Włochów, w rozumieniu zniesienia praw feudalnych i stworzenia oddzielnego państwa włoskiego, z którym Włosi mogliby się identyfikować.

Przedstawienie warunków prawno-politycznych, w jakich żył i tworzył Gian Domenico Romagnosi, stało się podstawą kolejnego referatu, wygłoszonego przez mgr. Łukasza Ciołka pt. „Podręcznik Principi fondamentali di diritto amministrativo Giana Domenico Romagnosiego i jego znaczenie dla nauki prawa administracyjnego".

Wystąpienie autora zostało poprzedzone uwagami dr. Wojciecha Tarasa w przedmiocie zasadności użycia słowa „podręcznik” odnośnie do dzieła Principi fondamentali di diritto amministrativo. W odpowiedzi na powyższe spostrzeżenie prelegent wskazał, że pojęcie „podręcznik” zostało użyte przez niego „na wyrost”. Faktycznie był to traktat odnoszący się do wielu materii i miał charakter interdyscyplinarny. Stanowił jednak jedną z pierwszych prób nadania akademickiego charakteru fragmentarycznym regulacjom z zakresu prawa administracyjnego na gruncie włoskim. W 1814 r. ukazało się pierwsze wydanie tego najważniejszego dzieła Podstawowych zasad prawa administracyjnego. Kolejne publikacje miały miejsce w 1932 i 1935 r. Prelegent podczas wystąpienia dokonał szczegółowej analizy sześciu ksiąg, z których składało się dzieło tego włoskiego uczonego. Pierwsze trzy księgi zawierają przede wszystkim rozważania o charakterze filozoficznym, księga czwarta szerzej odnosi się do kwestii ekonomicznych i własnościowych w działalności administracji publicznej, treść ostatnich dwóch ksiąg ma zaś charakter prawny. Traktat jest zakończony dodatkiem poruszającym kwestie wstępnych obserwacji dotyczących różnego rodzaju materii z zakresu działania administracji publicznej oraz odnoszącym się do kwestii ustrojowych zawartych w ówczesnej konstytucji włoskiej. Na zakończenie wystąpienia prelegent dokonał podsumowania, podkreślając znaczenie podręcznika dla nauki prawa administracyjnego. Podniósł, iż - po pierwsze - analizowane dzieło wskazało linię graniczną pomiędzy władzą administracyjną a sądowniczą. Po drugie, Romagnosi przypisał większą rolę stowarzyszeniom, określając rolę państwa jako zaledwie instrumentalną dla ekonomicznego rozwoju społeczności. Po trzecie, „podręcznik” ten był pierwszą próbą klasyfikacji funkcji pełnionych przez administrację publiczną. Po czwarte, w pracy tej zdefiniowano istotne pojęcia z zakresu prawa administracyjnego ze znaczącą precyzją.

W kolejnych referatach prelegenci szczegółowo odnieśli się do wybranych regulacji w prawie włoskim, co było cennym materiałem porównawczym dla uczestników konferencji w odniesieniu do instytucji i regulacji funkcjonujących w prawie polskim.

W referacie zatytułowanym „Spółdzielnie socjalne we włoskim systemie prawa publicznego" dr Tomasz Dąbrowski z Uniwersytetu Technologiczno-Humanistycznego w Radomiu przedstawił model włoskiej i polskiej spółdzielczości socjalnej. Wskazał, że we Włoszech zgodnie z ustawą 381/1991 wyróżniamy dwa 
typy spółdzielni socjalnych: typ A - zapewniający świadczenie usług społecznych, oraz typ B - zapewniający reintegrację społeczno-zawodową osób zagrożonych wykluczeniem społecznym. Prelegent podkreślił, że na gruncie włoskim znaczący wpływ na spółdzielnie socjalne ma wolontariat i konieczność uwzględnienia spółdzielni socjalnych w zamówieniach publicznych. Autor referatu odniósł się także do modelu polskiej spółdzielczości socjalnej, podkreślając, że w ostatnich latach obserwujemy rozkwit spółdzielni socjalnych również w Polsce. W ustawie o spółdzielniach socjalnych z dnia 27 kwietnia 2006 r. polski ustawodawca połączył wskazane wyżej dwa typy spółdzielni w jedną spółdzielnię społeczną. Prelegent wskazał też na konieczność przyszłych zmian legislacyjnych, w szczególności ustawy - Prawo spółdzielcze z dnia 16 września 1982 r.

Następny referat, zatytułowany „Koncepcja rzeczy publicznej w prawie włoskim”, został wygłoszony przez dr. hab. Leszka Bieleckiego z Uniwersytetu Jana Kochanowskiego w Kielcach i dotyczył koncepcji rzeczy publicznej na gruncie prawa polskiego i włoskiego. Prelegent wskazał, że podstawowe determinanty rzeczy publicznej to własność publiczna, cel publiczny, interes publiczny oraz publiczne prawo podmiotowe. Dokonał on podziału na rzecz publiczną w ujęciu infrastrukturalnym, fiskalnym, użytkowym i gospodarczym. Autor referatu odniósł się m.in. do poglądów Stanisława Kasznicy, wskazując, że rzecz publiczną stanowi majątek administracyjny, skarbowy oraz rzeczy powszechnego użytku. W prawie włoskim Księga III tytuł I włoskiego kodeksu cywilnego z 1942 r. dotyczy własności państwa, podmiotów publicznych i instytucji kościelnych. Cechą charakterystyczną włoskiej koncepcji rzeczy publicznej jest wydzielenie dóbr publicznych od innych dóbr oraz własności publicznej i prywatnej. Autor referatu wskazał, że na gruncie prawa włoskiego majątek państwowy nie wchodzi w skład dóbr publicznych.

Kolejny prelegent, mgr Piotr Świerczyński z Wydziału Prawa, Prawa Kanonicznego i Administracji KUL, w referacie pt. „Egzekucja administracyjna we włoskiej nauce prawa administracyjnego" wskazał, że egzekucja administracyjna we Włoszech całkowicie różni się od egzekucji prowadzonej na gruncie polskim, jedynie pod względem aksjologicznym są to podobne postępowania. Autor referatu szczegółowo opisał problematykę egzekucji administracyjnej we Włoszech, jej efektywność oraz rolę, jaką w Polsce pełni Centralne Biuro Łącznikowe, czyli Izba Skarbowa w Poznaniu.

W kolejnym referacie, zatytułowanym „Włoski samorząd zawodowy adwokatów po 2012 roku - Nuova disciplina dell'ordinamento della professione forense", mgr Marzena Świstak z Wydziału Prawa i Administracji UMCS zestawiła włoskie prawo samorządowe z polskimi regulacjami, w szczególności w zakresie realizacji obowiązku szkoleniowego i innych obowiązków wynikających z Kodeksu Etyki. W oparciu o powyższe prelegentka dokonała wnikliwej analizy orzeczenia Sądu Najwyższego w sprawie o sygn. akt SDI 32/14 z dnia 6 listopada 
2014 r., dotyczącego odpowiedzialności dyscyplinarnej za naruszenie obowiązku szkoleniowego przez radcę prawnego. Sąd Najwyższy w tym orzeczeniu stwierdził, że ustawowe przepisy regulujące kwestie obowiązku dokształcania się przez radców prawnych nie pozwalają na przyjęcie dopuszczalności karania osób uchylających się od tego obowiązku karami dyscyplinarnymi. Powyższe argumentowano faktem, że Kodeks Etyki Radców Prawnych, z którego wynika taki obowiązek, nie jest źródłem prawa w rozumieniu art. 87 Konstytucji z dnia 2 kwietnia 1997 r. W odniesieniu do wyżej wymienionego wyroku Sądu Najwyższego autorka referatu postawiła pytania w szerszym kontekście, zastanawiając się, czy taki kierunek wykładni może prowadzić do wniosku, że jeżeli konkretny obowiązek radcowski nie został sformułowany wprost $\mathrm{w}$ ustawie, to $\mathrm{w}$ takim przypadku uniemożliwia to sankcjonowanie takich zachowań. Prelegentka zastanawiała się też, czy zakres treści art. 64 ustawy o radcach prawnych z dnia 6 lipca 1982 r. jest wystarczający do uznania, że zachowania takie mają jednak umocowanie w ustawie. Jak podkreśliła, we Włoszech derogacja, którą ma ustawodawca, jest bardzo podobna jak w Polsce, a jednak nikt nie zauważa braku umocowania do stosowania tego rodzaju sankcji. Ponadto, w ocenie autorki wystąpienia, pojawia się problem, czy w wyroku Sądu Najwyższego nie doszło do „przemieszania” przez Sąd odpowiedzialności dyscyplinarnej z odpowiedzialnością karną, które nie mają charakteru tożsamego.

Następny referat dotyczył genezy banku centralnego na ziemiach polskich, wygłosiła go dr Eliza Kosieradzka z Wydziału Prawa i Administracji UMCS. Prelegentka zaprezentowała historię i początki bankowości na świecie i w Polsce. Jak wskazała, pomimo pierwszeństwa historycznego Banku Szwecji, wzorem banku centralnego dla innych krajów stał się Bank Anglii. Bank centralny w Europie powstał z banku emisyjnego i kredytowego, jako mieszanej instytucji pieniężnej, na przełomie XVII i XVIII w. Na tle historycznym autorka ukazała tworzącą się bankowość na ziemiach polskich, w szczególności w czasie rozbiorów Polski. Ponadto nakreśliła rolę, jaką odegrał Bank Polski założony w 1828 r. w rozwoju gospodarczym Królestwa Polskiego. Prowadził on nie tylko działalność emisyjną, ale także operacje kredytu obrotowego i inwestycyjnego. Bank Polski roztaczał ogólną opiekę nad przemysłem i handlem oraz brał czynny udział w tworzeniu ustroju kapitalistycznego, tworząc ważny rozdział dziejów gospodarczych Królestwa Polskiego. Autorka referatu wskazała też, że jego likwidacja była ostrym przejawem procesu rusyfikacji i dążenia do ścisłej integracji ziem polskich z Cesarstwem Rosyjskim. Jak podniosła, należy zgodzić się z R.W. Kaszubskim, że państwo istnieje w pełnym zakresie swej niepodległości wtedy, gdy działa jego bank centralny, emitujący pieniądz, który jest prawnym środkiem płatniczym na jego obszarze, a sytuacja w państwie wpływa na kierunek rozwoju banku centralnego tego państwa.

Reasumując, należy wskazać, że przedstawione wystąpienia nie tylko przypomniały postać włoskiego uczonego Giana Domenico Romagnosiego w szerokim 
polsko-włoskim kontekście historycznym epoki, w której żył, działał i tworzył, ale także wzbogaciły wiedzę uczestników konferencji w zakresie określonych instytucji prawnych funkcjonujących we Włoszech w zestawieniu z podobnymi instytucjami funkcjonującymi w systemie polskim. Konferencja ta była niezwykle cennym doświadczeniem poszerzającym horyzonty zarówno o elementy wiedzy historycznej, refleksje na temat poglądów Giana Domenico Romagnosiego na państwo i administrację, jak i o elementy przydatne w bieżącej prawniczej praktyce zawodowej. 